\title{
MENINGKATKAN PRESTASI BELAJAR SISWA DENGAN \\ MENERAPKAN MODEL PEMBELAJARAN COMPLETE SENTENCE DI KELAS V SDN 053979 KEPALA \\ SUNGAI
}

\author{
Matsum \\ Surel : matsummerah1111@gmail.com
}

\begin{abstract}
ABSTRAK
Tujuan penelitian ini adalah untuk mengetahui peningkatan prestasi belajar siswa dengan menerapkan model pembelajaran Complete Sentence pada mata pelajaran Bahasa Indonesia di kelas V SD Negeri 053979 Kepala Sungai T.A. 2015/2016". Metode penelitian ini adalah Penelitian Tindakan Kelas (Classroom Action Research). Pada siklus I dari 29 orang siswa yang menjadi subjek dalam penelitian ini, ada 16 siswa $(59,35 \%)$ yang memiliki ketuntasan belajar, sedangkan 13 siswa $(40,75 \%)$ belum memiliki ketuntasan belajar. Nilai rata-rata kelas yang diperoleh pada siklus I mencapai 68,8. Pada siklus II dari 29 siswa terdapat 27 siswa $(92,59 \%)$ yang telah mencapai ketuntasan belajar. Sedangkan 2 orang siswa $(7,41 \%)$ belum mencapai ketuntasan hasil belajar. Berdasarkan data tersebut terjadi peningkatan yang signifikan terhadap prestasi belajar siswa pada siklus II.
\end{abstract}

Kata Kunci : Bahasa Indonesia, Model Complete Sentence, Prestasi Belajar

\section{PENDAHULUAN}

Pengajaran bahasa indonesia bertujuan menjadikan siswa terampil menggunakan bahasa indonesia untuk berbagai situasi dan kondisi, baik secara lisan maupun tulisan. Belajar itu dapat berbentuk menyimak, membaca, berbicara, dan menulis. Salah satu keterampilan yang harus dikuasai oleh setiap siswa adalah keterampilan menulis. Melalui keterampilan menulis siswa dapat mengungkapkan ide, pikiran, perasaan, pengalaman baik pengalaman sendiri maupun orang lain. Kecermatan mengungkapkan hal-hal itu merupakan wujud dari kemampuan menulis.
Salah satu mata pelajaran yang diajarkan di sekolah dasar adalah bahasa indonesia. Bahasa indonesia pada sekolah dasar (SD) sangat penting dalam menumbuhkan dan mengembangkan pengetahuan dan kekreatifan pada saat belajar di kelas dapat menumbuhkan hal-hal yang baru baik dalam segi penilaian perkelompok maupun perindividu. Pada tingkat sekolah dasar siswa diharapkan mampu untuk mengembangkan dirinya dan meningkatkan pengetahuan dalam mempersiapkan diri untuk melanjutkan ke jenjang yang lebih tinggi. Pembelajaran bahasa Indonesia di kelas sangat 
membutuhkan kekreatifan dalam belajar apalagi dalam materi meringkas isi buku memang harus memiliki kekreatifannya dalam meringkas. Dalam pengajaran atau proses belajar mengajar guru memegang peran sebagai sutradara sekaligus aktor. Artinya, guru memegang tugas dan tanggung jawab merencanakan dan melaksanakan pengajaran di sekolah. Guru sebagai tenaga profesional harus memiliki sejumlah kemampuan mengaplikasikan berbagai teori belajar dalam berbagai pengajaran, kemampuan memilih dan menerapkan model pengajaran yang efektif dan efisien, kemampuan melibatkan siswa berpartisipasi aktif, dan kemampuan membuat suasana belajar yang menunjang tercapainya tujuan pendidikan.

Hal tersebut tidak menjadi pengecualian bagi guru bahasa Indonesia karena tidak dapat dipungkiri bahwa bahasa Indonesia merupakan salah satu pelajaran yang mempunyai peran yang penting dalam dunia pendidikan di negeri ini. Secara umum fungsi dan tujuan pembelajaran bahasa Indonesia adalah sebagai sarana: (1) sarana pembinaan kesatuan dan persatuan bangsa; (2) sarana peningkatan pengetahuan dan keterampilan berbahasa Indonesia dalam rangka pelestarian dan pengembangan budaya; (3) sarana peningkatan pengetahuan dan keterampilan berbahasa Indonesia dalam rangka meraih dan mengembangkan ilmu pengetahuan, teknologi, dan seni; (4) sarana penyebarluasan pemakaian bahasa Indonesia yang baik untuk berbagai keperluan menyangkut berbagai masalah; dan (5) sarana pengembangan penalaran.

Berdasarkan hasil pengamatan di kelas V SD Negeri 053979 Kepala Sungai permasalahan yang terjadi adalah :

1. Kemampuan siswa menceritakan pengalaman dalam pembelajaran Bahasa Indonesia rendah.

2. Penggunaan media pembelajaran yang tidak maksimal.

3. Siswa tidak memahami penyampaian yang diterapkan oleh guru.

4. Rendahnya hasil belajar siswa.

5. Sebagai guru kelas, saya juga menyadari bahwa banyak tujuan pembelajaran yang belum tercapai dikarenakan sulitnya mengatur KBM di dalam kelas serta sulitnya memberikan siswa tugas dikarenakan siswa jarang sekali mengumpul tugas tepat waktu.

Untuk mengatasi hal tersebut perlu diupayakan langkah-langkah yang dapat dilaksanakan baik oleh siswa maupun guru. Guru hendaknya mengemas proses belajar mengajar dengan model yang tepat dan menarik dalam penyajiannya. Salah satu model pembelajaran yang dipilih adalah Complete Sentence. Model pembelajaran Complete Sentence 
merupakan rangkaian proses pembelajaran yang diawali dengan menyampaikan materi ajar oleh guru, atau dengan penganalisaan terhadap modul yang telah dipersiapkan, pembagian kelompok yang tidak boleh lebih dari tiga orang dengan kemampuan yang heterogen, pemberian lembar kerja yang berisi paragraf yang belum lengkap, lalu diberikan kesempatan kepada siswa untuk berdiskusi dan diakhiri dengan pengambilan kesimpulan.

Dalam KBM di dalamnya terjadi interaksi antara siswa dan guru. Siswa perlu dididik untuk menjalankan program dan mencapai tujuan belajar. Salah satu tugas pendidik/guru adalah menciptakan suasana pembelajaran yang dapat membuat keadaan siswa menjadi senantiasa belajar dengan baik mampu mengembangkan kreativitasnya masing - masing. Guru dikatakan berhasil apabila pembelajaran yang diberikannya mampu merubah perilaku siswa kearah penguasaan kompetensi dasar yang lebih baik, dengan kata lain guru berpengaruh besar terhadap keberhasilan belajar siswanya.

Berdasarkan uraian latar belakang masalah di atas, sebagai guru kelas saya melakukan perbaikan pembelajaran melalui penelitian tindakan kelas yang berjudul "Upaya Meningkatkan Prestasi Belajar Siswa Dengan Menerapkan Model Pembelajaran Complete Sentence
Pada Mata Pelajaran Bahasa Indonesia di Kelas V SDN 053979 Kepala Sungai T.A. 2015/2016".

Adapun yang menjadi tujuan dalam penelitian ini adalah: "untuk mengetahui model pembelajaran Complete Sentence dapat meningkatkan prestasi belajar siswa pada mata pelajaran Bahasa Indonesia di kelas V SD Negeri 053979 Kepala Sungai T.A. 2015/2016".

\section{METODE PENELITIAN}

Metode penelitian ini adalah Penelitian Tindakan Kelas (Classroom Action Research). Pendekatan yang digunakan adalah pendekatan kualitatif yang berguna untuk mengungkapkan kesulitan belajar siswa dalam proses pembelajaran serta cara mengatasi kesulitan-kesulitan tersebut sebagai upaya untuk meningkatkan hasil belajar siswa pada materi tersebut.

Penelitian tindakan kelas (PTK) merupakan suatu proses dimana guru dan siswa menginginkan terjadinya perbaikan, peningkatan, dan perubahan pembelajaran yang lebih baik agar tujuan pembelajaran dikelas dapat tercapai secara optimal.

Disamping itu, penelitian tindakan kelas adalah salah satu strategi pemecahan masalah yang memanfaatkan tindakan nyata dan proses pengembangan kemampuan dalam mendeteksi dan memecahkan masalah. Bisa juga dikatakan bahwa penelitian tindakan kelas (PTK) 
merupakan suatu bentuk kajian yang bersifat reflektif oleh pelaku tindakan yang dilakukan untuk meningkatkan kemampuan rasional dari tindakantindakan yang dilakukannya itu, serta untuk memperbaiki kondisi nyata di mana praktek pelaksanaan pembelajaran tersebut dilakukan di dalam kelas. Penelitian tindakan kelas (PTK) bersifat reflektif artinya dalam proses penelitian itu anda sebagai guru sekaligus peneliti selalu memikirkan apa dan mengapa suatu dampak tindakan yang terjadi di kelas.

\section{HASIL DAN PEMBAHASAN Hasil Penelitian}

\section{Tabel 1. Hasil Belajar Siswa Pada} Saat Pretest

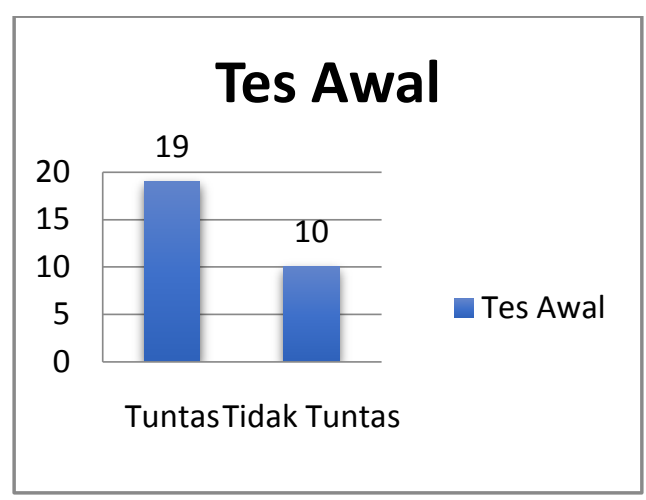

Berdasarkan data hasil tes Bahasa Indonesia materi Mendengarkan Pengumuman di atas dapat dilihat bahwa hasil belajar siswa dalam pembelajaran Bahasa Indonesia materi mendengarkan pengumuman masih rendah. Dari 29 orang siswa yang menjadi subjek dalam penelitian ini, ternyata hanya 10 orang siswa $(37,03 \%)$ yang sudah memiliki ketuntasan belajar, sedangkan selebihnya yaitu 19 orang siswa $(62,97 \%)$ belum memiliki ketuntasan belajar. Nilai rata-rata yang diperoleh hanya mencapai 66,7.

\section{Tabel 2. Hasil Belajar Siswa Pada Saat Siklus 1}

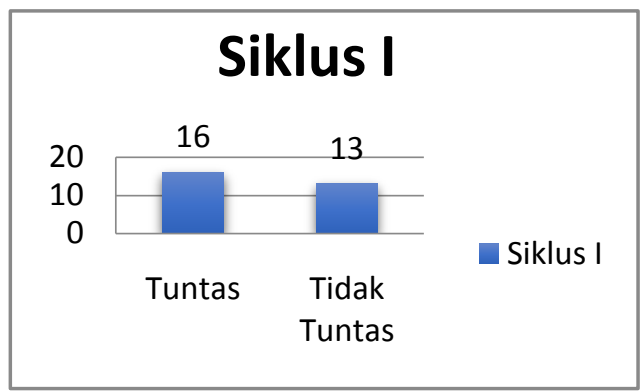

Berdasarkan tabel hasil Siklus I di atas dapat dilihat bahwa hasil belajar siswa dalam pembelajaran Bahasa Indonesia materi Mendengarkan Pengumuman ternyata telah mulai meningkat. Dari 29 orang siswa yang menjadi subjek dalam penelitian ini, ternyata telah ada 16 orang siswa $(59,35 \%)$ yang memiliki ketuntasan belajar, sedangkan 13 orang siswa $(40,75 \%)$ masih belum memiliki ketuntasan belajar. Nilai rata-rata kelas yang diperoleh pada siklus I ini mencapai 68,8 .

Dengan memperhatikan tabel di atas dapat dilihat bahwa analisis hasil belajar Bahasa Indonesia materi Mendengarkan Pengumuman siswa pada test siklus I ternyata hasilnya lebih baik dari data awal (pre test) walaupun hasilnya belum cukup 
maksimal, sehingga perlu dilanjutkan ke pelaksanaan siklus II, hal ini dapat dilihat dari kesalahan siswa dalam pelaksanaan pembelajaran Bahasa Indonesia materi Mendengarkan Pengumuman Bersama dan nilai ratarata yang diperoleh masih belum memenuhi kriteria ketuntasan minimal yang ditentukan sekolah.

Selanjutnya hasil belajar siklus I ini digunakan sebagai acuan dalam memberikan tindakan pada siklus II untuk mengatasi kesulitan siswa dalam mempelajari materi Bahasa Indonesia materi mendengarkan pengumuman.

Dari data yang didapat terlihat bahwa siswa hasil belajar dalam melakukan teknik-teknik Bahasa Indonesia materi mendengarkan pengumuman masih rendah, belum seperti yang diharapkan.

Adapun kegagalan yang terjadi dalam pelaksanaan tindakan pada siklus I dapat diuraikan sebagai berikut:

1. Guru wajib memberikan motivasi kepada siswa untuk lebih berperan tuntas dalam melakukan Bahasa Indonesia materi mendengarkan pengumuman dengan baik dan benar.

2. Siswa belum menguasai materi mendengarkan pengumuman

3. Guru belum secara maksimal dan rinci dalam mengontrol kegiatan diskusi siswa.
4. Siswa kurang tuntas berinteraksi bertanya kepada guru yang menjadi fasilitator.

5. Pembelajaran menggunakan model pembelajaran Complete Sentence pada siklus I belum sesuai dengan yang diharapkan dan hasil belajar Bahasa Indonesia materi mendengarkan pengumuman juga masih rendah karena ada 12 siswa (50) belum mencapai tingkat ketuntasan belajar.

\section{Tabel 3. Hasil Belajar Siswa Pada Saat Siklus 2}

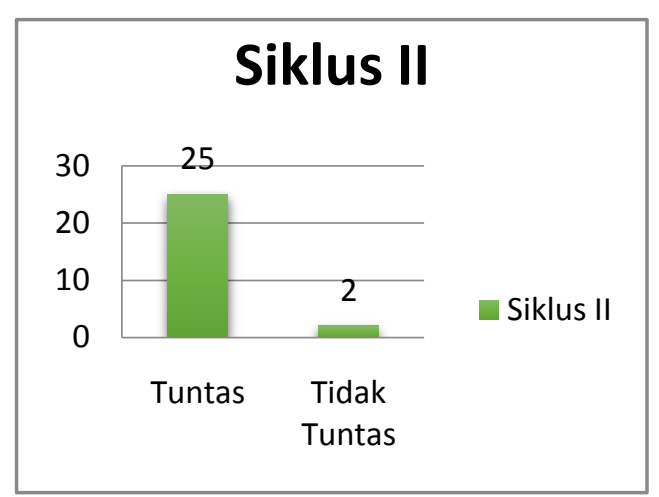

Berdasarkan tabel hasil Siklus II di atas dapat dilihat bahwa hasil belajar siswa dalam pembelajaran Bahasa Indonesia materi Mendengarkan Pengumuman ternyata telah mulai meningkat. Ternyata dari 29 orang siswa, terdapat 27 orang siswa yang tuntas $(92,59 \%)$ yang sudah memiliki ketuntasan belajar, sedangkan selebihnya yaitu 2 orang siswa $(7,41 \%)$ belum memiliki ketuntasan belajar. Nilai rata - rata 
yang diperoleh hanya mencapai 82,63 .

Maka dapat disimpulkan pada pembelajaran Bahasa Indonesia materi mendengarkan pengumuman melalui penerapan model pembelajaran Complete Sentence yang dituang pada tes hasil belajar I dan II mengalami peningkatan hasil belajar dan peningkatan ketuntasan belajar baik secara individual maupun klasikal. Adapun keberhasilan dan kegagalan yang terjadi dalam pelaksanaan tindakan pada siklus II dapat diuraikan sebagai berikut:

1. Guru sudah mampu secara maksimal dalam mengelola dan melaksanakan kegiatan belajar siswa dan menjelaskan materi mendengarkan pengumuman dengan menerapkan model pembelajaran Complete Sentence. Hal ini berdasarkan pada hasil belajar test II pada siklus II.

2. Siswa sudah mampu menguasai materi pengumuman yang dipilih sendiri dengan memperhatikan penggunaan ejaan dengan baik.

\section{Pembahasan Penelitian}

Melalui penerapan model pembelajaran Complete Sentence yang telah diterapkan pada siswa kelas kelas V SD Negeri 053979 Kepala Sungai T.A. 2015/2016, ternyata dapat meningkatkan ketuntasan hasil belajar Bahasa Indonesia materi mendengarkan pngumuman.
Pada Siklus I, dari 29 orang siswa yang menjadi subjek dalam penelitian ini, ternyata hanya 16 orang siswa $(59,25 \%)$ yang sudah memiliki ketuntasan belajar, sedangkan selebihnya yaitu 13 orang siswa $(40,75 \%)$ belum memiliki ketuntasan belajar. Nilai rata-rata yang diperoleh hanya mencapai 68,8 .

Hal inilah yang perlu dicermati oleh guru. Guru harus bisa memahami setiap perbedaan siswanya, namun guru harus tetap berusaha agar persentase siswa yang tuntas belajar Bahasa Indonesia materi Mendengarkan Pengumuman terus meningkat. Pada siklus I kegiatan pembelajaran yang terjadi diantaranya:

1. Guru mengarahkan siswa agar lebih tuntas dalam mengeluarkan pendapat.

2. Guru menerapkan aturan-aturan agar siswa patuh terhadap aturan yang berlaku dalam setiap berpasangan.

3. Setelah belajar mandiri dilakukan guru memberikan kembali penjelasan dan koreksi secara keseluruhan kepada siswa dan selanjutnya melaksanakan tes hasil belajar I.

Analisis hasil belajar Bahasa Indonesia materi mendengarkan pengumuman siswa pada tes I siklus I ternyata hasilnya lebih baik dari data awal walaupun hasilnya belum cukup maksimal, sehingga perlu dilanjutkan ke pelaksanaan siklus II. Pada siklus 
I, guru menemukan kesulitan yang dialami siswa dan guru dalam pembelajaran diantaranya yaitu:

1. Pada pelaksanaan model pembelajaran Complete Sentence yang digunakan yaitu dimana siswa belum mampu berfikir kreatif.

2. Kerjasama antar berpasangan masih tergolong kacau.

Pembelajaran menggunakan menghargai keputusan bersama pada siklus I ini belum sesuai dengan yang diharapkan dan hasil belajar siswa juga masih rendah. Kemudian pada siklus II dapat dilihat bahwa telah ada peningkatan tuntasitas siswa dari siklus sebelumnya. Dari tes analisis yang dilakukan dapat disimpulkan bahwa telah terjadi peningkatan kemampuan siswa. Peningkatan ini terjadi setelah diberikan pembelajaran melalui penerapan menghargai keputusan bersama yang dirancang pada siklus II yang beracuan pada refleksi dan pengalaman pada siklus I.

Sedangkan pada siklus II dapat dilihat bahwa kemampuan siswa dalam melakukan tes hasil belajar secara klasikal sudah meningkat. Sedangkan pada siklus II dapat dilihat bahwa kemampuan siswa dalam melakukan tes hasil belajar secara klasikal sudah meningkat. Ternyata dari 29 orang siswa, terdapat 27 orang siswa yang tuntas $(92,59 \%)$ yang sudah memiliki ketuntasan belajar, sedangkan selebihnya yaitu 2 orang siswa $(7,41 \%)$ belum memiliki ketuntasan belajar. Nilai rata-rata yang diperoleh hanya mencapai 82,63.

Pengamatan selama berlangsungnya kegiatan belajar mengajar mengamati kemampuan siswa mulai dari awal pelaksanaan pembelajaran Bahasa Indonesia materi mendengarkan pengumuman sampai berakhirnya tindakan Bahasa Indonesia materi mendengarkan pengumuman. Adapula keberhasilan yang terjadi dalam pelaksanaan tindakan siklus II adalah sebagian besar siswa sudah mampu menguasai materi dengan baik dan benar. Hasil pengamatan refleksi II setelah pengamatan dilaksanakannya kegiatan belajar mengajar pada siklus II diperoleh hasil bahwa adanya Peningkatan hasil belajar Bahasa Indonesia pada siswa/siswi kelas kelas V SD Negeri 053979 Kepala Sungai T.A. 2015/2016.

Penanaman nilai dan sikap dalam pembelajaran bahasa Indonesia sebaiknya dipersiapkan dan dirancang secara berkesinambungan dengan perbedaan penekanan pada setiap tingkatan. Semakin tinggi tingkatnya, semakin besar unsur pemahaman dan pertanggung jawabannya. Oleh karena pembelajaran Bahasa Indonesia dilaksanakan dalam waktu yang terbatas, maka tidak mungkin memperkenalkan seluruh nilai kehidupan kepada siswa. 
Keberhasilan siswa dapat ditentukan dari beberapa faktor antara lain faktor internal dan eksternal. Faktor yang timbul dari dalam diri siswa, antara lain kemauan, rasa takut, tingkat intelektual dan sebagainya. Sedang faktor eksternal dapat berupa sikap guru, pendekatan pengajaran, model, alat peraga, dan sumber-sumber lain. Kesemuanya itu akan berpengaruh terhadap keberhasilan pembelajaran.

Kebanyakan guru menerapkan pembelajaran Bahasa Indonesia melalui berceramah dan diskusi, hal ini akan semakin membuat siswa merasa bosan ketika pembelajaran. Di masa era globalisasi ini, pengaruh IPTEK cukup membuat mental siswa bobrok, sehingga ketika guru tidak mampu melaksanakan pembelajaran akan semakin menurunkan minat dan motivasi siswa terhadap pembelajaran yang dilaksanakan.

Perlunya guru meningkatkan kualitas belajar mengajar disebabkan karena banyaknya pengaruh dari berbagai hal. Model Pembelajaran Complete Sentence ini bertujuan untuk memberikan cara bagi siswa untuk membangun kecakapankecakapan intelektual (kecakapan berfikir) terkait dengan proses-proses berfikir reflektif. Jika berfikir menjadi tujuan utama dari pendidikan, maka harus ditemukan cara-cara untuk membantu individu untuk membangun kemampuan itu.

$$
\text { Pembelajaran }
$$

Complete

Sentence ini dapat meningkatkan hasil belajar siswa dalam pembelajaran Bahasa Indonesia, karena dalam pembelajaran Complete Sentence dapat melatih siswa untuk belajar mandiri, karena masing-masing siswa diberikan tugas untuk membuat satu pertanyaan, lalu pertanyaan itu akan dijawab oleh temannya atau sebaliknya. Kemudian menumbuhkan kreaktivitas belajar siswa karena membuat bola sebagaimana yang diinginkannya dan belajar lebih hidup, karena semua siswa aktif membuat pertanyaan ataupun menjawab soal temannya yang jatuh pada dirinya. Berdasarkan data dari siklus II, menunjukan hasil belajar siswa telah meningkat hingga 92,59\%. Dan berdasarkan hal itu maka dapat ditarik kesimpulan bahwa "terjadi peningkatan prestasi belajar siswa dengan menerapkan model pembelajaran Complete Sentence pada mata pelajaran Bahasa Indonesia di kelas V SD Negeri 053979 Kepala Sungai Tahun Ajaran. 2015/2016".

\section{SIMPULAN}

Pada siklus I dari 29 orang siswa yang menjadi subjek dalam penelitian ini, ternyata telah ada 16 orang siswa $(59,35 \%)$ yang memiliki ketuntasan belajar, sedangkan 13 orang siswa $(40,75 \%)$ masih belum memiliki ketuntasan belajar. Nilai rata-rata kelas yang diperoleh pada siklus I ini mencapai 68,8. Pada siklus II dari 29 siswa terdapat 27 siswa $(92,59 \%)$ yang telah mencapai ketuntasan belajar. Sedangkan 2 
orang siswa $(7,41 \%)$ belum mencapai ketuntasan klasikal hasil belajar siswa telah meningkat dari hasil pada siklus I. Dan berdasarkan data tersebut maka dapat ditarik kesimpulan bahwa "terjadi peningkatan prestasi belajar siswa dengan menerapkan Model Pembelajaran Complete Sentence pada mata pelajaran Bahasa Indonesia di kelas V SD Negeri 053979 Kepala Sungai Tahun Ajaran 2015/2016".

\section{DAFTAR RUJUKAN}

Depdiknas. (2004). Pedoman Proses Belajar Mengajar di SD. Jakarta: Proyek Pembinaan Sekolah Dasar.

Hamalik, Oemar. (2010). Kurikulum dan Pembelajaran. Jakarta: Bumi Aksara.

Hamdani (2011). Strategi Belajar Mengajar. Bandung: Pustaka Setia.

Istarani (2011). 58 Model Pembelajaran Inovatif. Medan: Media Persada.

Istarani (2012). Kumpulan 39 Metode Pembelajaran. Medan : Iscom Medan.

Nurjamal, Daeng dan Warta Sumirat. (2010). Penuntun Perkuliahan Bahasa Indonesia. Bandung: Alfabeta.
Ridwan Abdul Sani (2013). Inovasi Pembelajaran. Jakarta: Bumi Aksara.

Rosmala, Dewi. (2010). Penelitian Tindakan Kelas. Medan: Pascasarjana Unimed.

Sardiman. (2006). Interaksi Belajar Mengajar. Jakarta: Raja Grafindo

Sarwiji Suwandi. (2004). Penelitian Tindakan Kelas (PTK) \& Penulisan Karya Ilmiah. Surakarta: Yuma Pustaka.

Slameto (2010). Belajar Dan FaktorFaktor Yang Mempengaruhi. Jakarta : Rineka Cipta.

Suharsimi Arikunto. (2010). Penelitian Tindakan Kelas. Jakarta: Rineka Cipta.

Syah, Muhibbin (2006). Psikologi Belajar. Jakarta: Logos.

Wina Sanjaya (2011). Strategi Pembelajaran Berorientasi Standard Proses Pendidikan. Bandung: Kencana Prenada Media. 